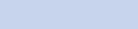

\title{
Decreased prevalence of hypercholesterolaemia and stabilisation of obesity trends in 5-year-old children: possible effects of changed public health policies
}

\author{
Katarina Sedej ${ }^{1}$, Primož Kotnik ${ }^{1}$, Magdalena Avbelj Stefanija ${ }^{1}$, Urh Grošelj ${ }^{1}$, \\ Andreja Širca Čampa ${ }^{1}$, Lara Lusa ${ }^{2}$, Tadej Battelino ${ }^{1,3}$ and Nataša Bratina ${ }^{1}$ \\ ${ }^{1}$ Department of Endocrinology, Diabetes and Metabolism, University Children's Hospital, University Clinical Centre \\ Ljubljana, Bohoričeva 20, SI-1000 Ljubljana, Slovenia, ${ }^{2}$ Faculty of Medicine, Institute of Biostatistics and Medical \\ Informatics, University of Ljubljana, Vrazov trg 2, Ljubljana, Slovenia and ${ }^{3}$ Faculty of Medicine, University of \\ Ljubljana, Vrazov trg 2, Ljubljana, Slovenia
}

\author{
Correspondence \\ should be addressed \\ to N Bratina \\ Email \\ natasa.bratina@kks-kamnik.si
}

\section{Abstract}

Background: Overweight/obesity in children is a worldwide public health problem. Together with hypercholesterolaemia they are associated with early atherosclerotic complications.

Objectives: In this study, we aimed to investigate the anthropometric characteristics and total cholesterol (TC) levels in a population of 5-year-old children, to determine trends in the prevalence of overweight/obesity and hypercholesterolaemia in 5-year-old children over a period of 8 years (2001-2009) and to assess the impact of modified national nutritional guidelines for kindergartens implemented in 2005.

Design: Cross-sectional studies of overweight/obesity prevalence in the years 2001, 2003-2005 and 2009, and hypercholesterolaemia in years 2001 and 2009, in 5-year-old children.

Subjects: Altogether, 12832 (6308 girls/6524 boys) children were included.

Methods: Overweight/obesity was defined by IOTF criteria. Hypercholesterolaemia was defined by TC level $>5 \mathrm{mmol} / \mathrm{l}$. Multivariable logistic regression models were used.

Results: No correlation between BMI values and TC levels was found. Overweight and obesity prevalence were stabilised from 2001 to 2009 (odds ratio (OR) (95\% Cl): $1.13(0.99-1.3)$ and $1.13(0.89-1.42)$ respectively). Girls were more frequently overweight/obese than boys (OR (95\% Cl): $0.71(0.65-0.79)$ and $0.75(0.64-0.89)$ respectively). Prevalence of hypercholesterolaemia significantly decreased from 2001 to 2009 (OR (95\% Cl): $0.47(0.41-0.55)$ ). It was less frequent in boys than in girls (OR (95\% Cl): $0.7(0.61-0.8)$ ).

Conclusions: This is the first study to describe a negative trend in the prevalence of hypercholesterolaemia in pre-pubertal children. In addition, the prevalence of overweight/obesity in these children has been stabilised. Nationwide changes in public health policies could have influenced these observations.

\section{Introduction}

Obesity in children is a major health problem of global significance $(1,2)$. Until very recently the prevalence was increasing. However, in the last couple of years several studies from various countries worldwide reported that the prevalence of childhood obesity is reaching a plateau or is even slightly decreasing $(3,4)$. Nevertheless, it is still too high. Complications of obesity, such as hypertension, impaired glucose regulation, fatty liver, systemic 
inflammation and premature signs of atherosclerosis, are already identified in childhood. Furthermore, obese children have a higher prevalence of dyslipidaemia (5), and the prevalence of metabolic syndrome in children is increasing with the degree of obesity $(6,7)$. Obese children are at greater risk of becoming obese adults and prematurely develop cardiovascular diseases (CVD) (8).

Hypercholesterolaemia in children is another risk factor for early development of atherosclerosis and CVD (9). Hypercholesterolaemia in children most often has a polygenic aetiology. Familial hypercholesterolaemia (FH) with an incidence of $1 / 500$ is the most common primary dyslipidaemia in childhood (10). Primary CVD prevention measures similar to those in obesity are crucial, including strategies to identify individuals at high risk (e.g. children with $\mathrm{FH}$, children with morbid obesity), and populationbased strategies to reduce rates of hypercholesterolaemia and/or obesity (e.g. promotion of healthy diet, physical activity, etc.) (11).

Slovenia is - according to the available data - currently the only country worldwide with the universal screening for hypercholesterolaemia, which was introduced as a part of mandatory nationwide medical examination in the year 1995 for 5-year-old children (12). The decision to introduce a universal general screening in children at this age was based on the fact that the process of atherosclerosis starts early in the childhood, cholesterol levels can be discriminated best between people with and without $\mathrm{FH}$ at the age of 1-9 years, dyslipidaemia in children is virtually asymptomatic and at the age of 5 years nutritional intervention can already be advised $(12,13$, 14). Only recently, a universal screening for hypercholesterolaemia in pre-pubertal children was recommended by the National Lipid Association in the USA, as a preferred method of screening for hypercholesterolaemia in primary prevention efforts (15).

Previous nationally representative studies on obesity prevalence and total cholesterol (TC) levels in the Slovenian 5-year-old children were performed in the years 2001 and 2003-2005 (overweight and obesity only) $(16,17)$. In the year 2005, new national nutritional guidelines for the preparation of meals in kindergartens and schools were adopted in Slovenia, advocating decreased total fat and carbohydrate intake (18). As over $75 \%$ of the Slovenian 5-year-old children visit kindergarten (19), the new guidelines could have had some population-wide impact.

The main objectives of this study were to investigate the anthropometric characteristics and TC levels in a population of 5-year-old children and to determine trends in the prevalence of overweight/obesity and of hypercholesterolaemia in 5-year-old children over a period of 8 years (2001-2009), which could reflect new nutritional guidelines for kindergartens adopted in the year 2005.

\section{Subjects and methods}

Data were obtained from 5-year-old children on the occasion of a mandatory nationwide medical examination. Children were formally invited to attend the examination, as a rule close to their fifth birthday, by their chosen medical care provider in their local medical institution. During the examination blood collection (venous blood in EDTA) for the determination of blood count and TC was carried out. Children did not need to be in a fasted state. TC value $<5 \mathrm{mmol} / \mathrm{l}$ was considered normal. If a TC value between 5.0 and $6.0 \mathrm{mmol} / \mathrm{l}$ was determined, a fasting lipid profile was performed (TC, LDL, HDL and triglycerides) $(12,20)$. However, as the screening data on TC were collected anonymously, follow-up fasting lipid profiles were not available.

Altogether, 12832 children from all parts of the country were included in the study. For the purpose of the study, Slovenia was divided into 12 regions of residency. First, data from 5406 children (49\% girls and $51 \%$ boys) examined in year 2009 were analysed. Furthermore, to determine trends for the period 2001-2009, also data from 2742 randomly selected children (48\% girls and 52\% boys) examined in year 2001 and data from 4684 children (49\% girls and 51\% boys) examined in years 2003-2005 (overweight and obesity data only) were reanalysed, enabling comparisons $(16,17)$. The study was approved by the National Medical Ethics Committee (\#25/10/09).

\section{Anthropometric characteristics}

The height and weight were measured by a trained nurse using validated stadiometers and electronic digital scales. Both were rounded to the tenth decimal place. BMI was calculated as weight $(\mathrm{kg})$ divided by squared height $\left(\mathrm{m}^{2}\right)$.

Overweight and obesity were defined by the IOTF criteria (21) corresponding to adult's BMI cut-offs of 25 and $30 \mathrm{~kg} / \mathrm{m}^{2}$ at 18 years of age. These criteria define age- and sex-specific cut-off points from 2- to 18 -year-old children.

\section{Laboratory methods}

TC level was determined by cholesterol-oxidase/ p-aminofenazon (CHOD-PAP) method in the laboratories 
of participating primary health care facilities, according to manufacturer's instructions. The fact that this method remained unchanged throughout the study was ascertained by a questionnaire. TC levels $>5 \mathrm{mmol} / \mathrm{l}$ were considered elevated (22).

\section{Statistical analysis}

Data from descriptive statistics were reported as numbers and percentages of subjects who were overweight (including the obese), obese or had hypercholesterolaemia (with its 95\% CI), separately for males and females. Numerical variables were summarised as means (interquartile range). Mean TC levels were compared using Welch two-sample $t$-test and reporting 95\% CI for the mean differences. Multivariable logistic regression models were used to investigate the association between being overweight and sex, calendar year of the survey and region of residence; an interaction term between sex and year was also included in the models. Results were reported as odds ratio (OR) with their 95\% CI and $P$ values. The statistical significance of the interaction between sex and calendar year was tested using the likelihood ratio test; non-significant interactions were removed from the models. The multivariable modelling approach was used as it allowed us to disentangle the effect of each studied variable separately. The reference value of the OR calculated for the regions was the overall average value. Similar analyses were performed using obesity and hypercholesterolaemia as outcomes. The association between BMI and TC level (used as a numerical variable) was assessed using Spearman's correlation $(r)$. R statistical language was used for the statistical analyses (23).

\section{Results}

After the exclusion of subjects with missing data (either weight, height or TC, altogether 278 subjects) the core dataset comprised 12832 5-year-old children for the analysis of trends in overweight/obesity (examined in years 2001, 2003-2005 and 2009) and 7554 5-year-old children for the analysis of trends in TC levels (examined in years 2001 and 2009).

\section{Anthropometric characteristics and TC levels}

The anthropometric characteristics of the subjects and the prevalence of overweight/obesity are presented in Table 1. Mean TC level of 5-year-old children in 2009 decreased from 4.4 to $4.1 \mathrm{mmol} / 1$ in year 2001 (mean difference= 0.26 , 95\% CI: $0.23-0.30 \mathrm{mmol} / \mathrm{l}, P<0.001)$; the mean decrease was statistically significant also when girls and

Table 1 Anthropometric data and overweight/obesity prevalence (and change in prevalence) for 5-year-old girls and boys in the period from 2001 to 2009.

\begin{tabular}{|c|c|c|c|c|c|}
\hline & \multirow[b]{2}{*}{2001} & \multirow[b]{2}{*}{2004} & \multirow[b]{2}{*}{2009} & \multicolumn{2}{|c|}{$\Delta$ From $2001 \%(95 \% \mathrm{Cl})$} \\
\hline & & & & 2004 & 2009 \\
\hline \multicolumn{6}{|c|}{ Subjects $(n)$} \\
\hline & 1325 & 2317 & 2666 & & \\
\hline & 1417 & 2367 & 2830 & & \\
\hline \multicolumn{6}{|c|}{ BMI $\left(\mathrm{kg} / \mathrm{m}^{2} ;\right.$ median (IQR)) } \\
\hline Girls & $15.3(14.4-16.5)$ & $15.4(14.4-16.5)$ & $15.5(14.5-16.5)$ & & \\
\hline Boys & $15.4(14.6-16.5)$ & $15.4(14.6-16.5)$ & $15.5(14.6-16.6)$ & & \\
\hline \multicolumn{6}{|c|}{ Prevalence $(n(\%) ; 95 \% \mathrm{Cl})$} \\
\hline \multicolumn{6}{|c|}{ Overweight } \\
\hline All & $\begin{array}{c}387 / 2742(14.1) \\
12.9-15.5\end{array}$ & $\begin{array}{c}684 / 4684(14.6) \\
13.6-15.6\end{array}$ & $\begin{array}{c}848 / 5406(15.7) ; \\
14.7-16.7\end{array}$ & $0.5(-1.2$ to 2.2$)$ & $1.5(-0.1$ to 3.2$)$ \\
\hline Girls & $\begin{array}{c}209 / 1325(15.8) \\
13.9-17.8\end{array}$ & $\begin{array}{c}387 / 2317(16.7) \\
15.2-18.2\end{array}$ & $\begin{array}{c}486 / 2666(18.2) ; \\
16.8-19.7\end{array}$ & $0.9(-1.6$ to 3.5$)$ & $2.4(0.0$ to 5.0$)$ \\
\hline Boys & $\begin{array}{c}178 / 1417(12.6) \\
10.9-14.4\end{array}$ & $\begin{array}{c}297 / 2367(12.6) ; \\
11.3-13.9\end{array}$ & $\begin{array}{c}362 / 2740(13.2) \\
12.0-14.5\end{array}$ & $0.0(-2.2$ to 2.2$)$ & $0.6(-1.5$ to 2.8$)$ \\
\hline \multicolumn{6}{|l|}{ Obese } \\
\hline All & $\begin{array}{c}126 / 2742(4.6) \\
3.9-5.44\end{array}$ & $\begin{array}{c}207 / 4684(4.4) \\
3.9-5.1\end{array}$ & $\begin{array}{c}283 / 5406(5.2) \\
4.7-5.9\end{array}$ & $-0.2(-1.2$ to 0.8$)$ & $0.6(-0.4$ to 0.7$)$ \\
\hline Girls & $\begin{array}{c}71 / 1325(5.4) \\
4.3-6.7\end{array}$ & $\begin{array}{c}110 / 2317(4.7) \\
4.0-5.7\end{array}$ & $\begin{array}{c}164 / 2666(6.2) \\
5.3-7.1\end{array}$ & $-0.8(-2.2$ to 0.9$)$ & $0.8(-0.8$ to 2.4$)$ \\
\hline Boys & $\begin{array}{c}55 / 1417(3.9) \\
3.0-5.0\end{array}$ & $\begin{array}{c}97 / 2367(4.1) \\
3.4-5.0\end{array}$ & $\begin{array}{c}119 / 2740(4.3) \\
3.6-5.2\end{array}$ & $0.2(-1.1$ to 1.6$)$ & $0.4(-0.9$ to 1.8$)$ \\
\hline
\end{tabular}


Table 2 Elevated total cholesterol (TC) level prevalence for 5-year-old boys and girls and mean values for TC according to sex in the years 2001 and 2009.

\begin{tabular}{|c|c|c|c|c|c|}
\hline & \multirow[b]{2}{*}{2001} & \multirow[b]{2}{*}{2009} & \multicolumn{3}{|c|}{ Difference 2001-2009 } \\
\hline & & & $\Delta$ & $\Delta 95 \% \mathrm{Cl}$ & $P$ \\
\hline \multicolumn{6}{|l|}{$\mathrm{TC}>5 \mathrm{mmol} / \mathrm{l}(n(\%) ; 95 \% \mathrm{Cl})$} \\
\hline Girls & $\begin{array}{c}291 / 1325(22.0) \\
14.6-18.5\end{array}$ & $\begin{array}{c}256 / 2381(10.8) \\
9.6-12.1\end{array}$ & $11.2 \%$ & $8.6-13.8$ & $<0.001$ \\
\hline Boys & $\begin{array}{c}233 / 1417(16.4) \\
19.8-24.3\end{array}$ & $\begin{array}{l}191 / 2431(7.9) \\
6.9-9.0\end{array}$ & $8.6 \%$ & $6.3-10.8$ & $<0.001$ \\
\hline \multicolumn{6}{|l|}{$\mathrm{TC}(\mathrm{mmol} / \mathrm{l})$, mean $(95 \% \mathrm{Cl})$} \\
\hline Girls & $4.5(4.42-4.50)$ & $4.2(4.16-4.22)$ & 0.27 & $0.22-0.32$ & $<0.001$ \\
\hline Boys & $4.3(4.29-4.37)$ & $4.1(4.05-4.10)$ & 0.25 & $0.20-0.30$ & $<0.001$ \\
\hline
\end{tabular}

boys were analysed separately (Table 2). Mean and median TC levels were very similar due to the symmetric distribution. Girls compared with boys had $0.11 \mathrm{mmol} / 1$ higher mean TC levels (95\% CI: 0.07-0.15, $P<0.001$ ) in year 2009 (as compared with $0.13 \mathrm{mmol} / 1$ in year 2001, 95\% CI: 0.07-0.19, P<0.001) (Table 2). Median TC levels decreased from 4.4 to $4.2 \mathrm{mmol} / \mathrm{l}$ in girls and from 4.3 to $4.0 \mathrm{mmol} / 1$ in boys. Ninety-fifth percentile TC levels values decreased in girls from 5.8 to $5.4 \mathrm{mmol} / 1$ and in boys from 5.6 to $5.3 \mathrm{mmol} / \mathrm{l}$. BMI and TC levels were found not to be associated $(r=0.031)$; the lack of association persisted when the data were analysed separately for boys $(r=0.06)$ and for girls $(r=0.001)$.

\section{Trends in overweight/obesity prevalence from 2001 to 2009}

The prevalence of overweight was altogether stable (Table 1). In girls there was a positive but statistically non-significant $(P=0.11)$ trend from $15.8 \%$ in 2001 to $16.7 \%$ in 2004 (0.9\% difference, $95 \% \mathrm{CI}:-1.6$ to $3.5 \%)$ and to $18.2 \%$ in 2009 (difference from 2001: 2.4\%, 95\% CI:
$0-5 \%)$. In boys the prevalence remained stable $(P=0.50)$ : $12.6 \%$ in 2001, 12.6\% in 2004 and $13.2 \%$ in 2009.

In the multivariable logistic model for overweight (including obesity), the interaction between sex and survey year was not statistically significant $(P=0.7)$ and was removed from the model. As shown in Table 3, boys had a significantly lower probability of being overweight compared with girls and the probability of being overweight remained unchanged from 2001 to 2005, while there was a non-significant trend towards an increase in 2009.

Trends in the prevalence of obesity were similar as for overweight (Table 1). Prevalence of obesity was $5.4 \%$ in 2001, 4.7\% in 2004 and 6.2\% in $2009(P=0.10)$ in girls and $3.9 \%$ in 2001, 4.1\% in 2004 and 4.3\% in $2009(P=0.10)$ in boys. Results from the multivariable analysis were similar to those reported for overweight.

The interaction between sex and year was not statistically significant $(P=0.5)$. As shown in Table 3 , boys were less likely to be obese than girls and the probability of being obese did not change significantly from 2001 to 2005 and 2009.

Table 3 Odds ratios of being overweight, obese or have total cholesterol (TC) level $>5 \mathrm{mmol} / \mathrm{l}$ and sex and survey year as determined by multivariable logistic regression models.

\begin{tabular}{l}
\hline \\
\hline Sex \\
Girls \\
Boys \\
Year \\
2001 \\
2005 \\
2009
\end{tabular}

OR

Overweight

\begin{tabular}{llc}
1 & & \\
0.71 & $0.65-0.79$ & $\begin{array}{c}0.01 \\
0.1\end{array}$ \\
1 & & 0.86 \\
1.01 & $0.87-1.18$ & 0.08 \\
1.13 & $0.99-1.3$ & 0.3 \\
\hline
\end{tabular}

\begin{tabular}{|c|c|c|}
\hline \multicolumn{3}{|c|}{ Obesity } \\
\hline OR & $95 \% \mathrm{Cl}$ & $P$ \\
\hline 1 & & \\
\hline 0.75 & $0.64-0.89$ & $\begin{array}{c}<0.01 \\
0.1\end{array}$ \\
\hline 1 & & \\
\hline 0.95 & $0.74-1.23$ & 0.72 \\
\hline 1.13 & $0.89-1.42$ & 0.32 \\
\hline
\end{tabular}

\begin{tabular}{|c|c|c|}
\hline \multicolumn{3}{|c|}{$\mathrm{TC}>5 \mathrm{mmol} / \mathrm{l}$} \\
\hline OR & $95 \% \mathrm{Cl}$ & $P$ \\
\hline 1 & & \\
\hline 0.7 & $0.61-0.8$ & $<0.01$ \\
\hline 1 & & \\
\hline NA & NA & NA \\
\hline 0.47 & $0.41-0.55$ & $<0.01$ \\
\hline
\end{tabular}

NA, not applicable. 


\section{Trends in hypercholesterolaemia prevalence from 2001 to 2009}

The prevalence of 5-year-old children with hypercholesterolaemia (TC levels $>5 \mathrm{mmol} / \mathrm{l}$ ) significantly decreased in girls from $22 \%$ in 2001 to $10.8 \%$ in $2009(P<0.001)$ and in boys from $16.4 \%$ in 2001 to $7.9 \%$ in $2009(P<0.001)$ (Table 2).

In the multivariable model, the interaction between sex and survey year was not statistically significant $(P=0.6)$. As shown in Table 3, OR for hypercholesterolaemia in 5-year-old children were significantly lower in 2009 than in 2001 and in boys.

There was a significant variability across regions $(P<0.01)$. A region in the north-eastern part of Slovenia, bordering Austria, was identified as having significantly higher prevalence of hypercholesterolaemia (Podravska, OR (95\% CI): 1.37 (1.18-1.58); $P<0.01)$. Interestingly, a region bordering Italy had a significantly decreased prevalence (Goriška, OR (95\% CI): 0.81 (0.67-0.96); $P=0.02)$. Other regions did not differ from the mean.

\section{Discussion}

\section{Trends in overweight/obesity prevalence from 2001 to 2009}

Slovenia had a total population of 2 million inhabitants and an average number of $\sim 180005$-year-old children per generation in the observational period (19). Using nationally representative data, trends in overweight and obesity prevalence in 5-year-old children were determined. The main finding of this study, related to childhood obesity, is that overweight and obesity prevalence (estimated by BMI) in 5-year-olds did not increase. Nevertheless, the prevalence of overweight and obesity is still too high.

Use of IOTF standards in this study has allowed comparison with several other European countries and the USA. The prevalence of overweight and obesity in 5 -year-old Slovenian children in 2009 is comparable to European countries like France $(\sim 18 \%$ prevalence of overweight and obesity in 4-year-old children) (24). The determined prevalence is, however, lower than in other Mediterranean countries such as (neighbouring country) Italy, Greece and Spain and in the British Isles (24).

Stabilisation of the overweight/obesity prevalence in young children is in concordance with very recent findings from several European countries (3). In Germany, the prevalence of overweight and obesity is high, but the trends have stabilised from 2004 to 2008 (4, 25). In England, overweight and obesity in 5- to 10-year-old children have also stabilised recently (26). Prevalence of overweight and obesity has also been stabilised in Sweden, Greece and in The Netherlands (in children of Dutch ethnicity) (27). In addition, our results are also in concordance with the data from the USA where the prevalence of overweight children is not increasing any more since 2000, except in the most obese boys (28). In France, the prevalence of overweight and obesity in 5- to 12-year-old children has even decreased, similarly as in 6- to 13-year-old children in Switzerland $(29,30)$. It is interesting that while the prevalence of obesity is stabilising this appears to happen on different levels. Different genetic and environmental (cultural) backgrounds possibly contribute to this fact (3).

There is a significant difference in the prevalence of overweight and obesity between 5-year-old boys and girls, being higher in girls. Similar sex-specific difference is observed in the French and Dutch cohorts $(27,31)$. In our cohort, this gender difference increased over time, as the trend towards stabilisation of overweight/obesity prevalence was more pronounced in boys than in girls. This finding is not in accordance with data from several other countries, where there was a greater stabilisation in the prevalence in girls (3). Again different social status and cultural background can be attributed to this variability (3).

\section{Trends in hypercholesterolaemia prevalence from 2001 to 2009}

The main finding of this study is the significant negative trend in the prevalence of hypercholesterolaemia in 5-year-old children from 2001 to 2009. To our knowledge, this is the first study to report such results in pre-pubertal children. In addition, this is the first cross-sectional study where a specific cause was identified that could have influenced the negative trend.

As the influence of the genetic background on TC levels did not change, we speculate that the change in diet (cholesterol intake) of Slovenian 5-year-old children could have influenced the observed trend. Unfortunately, our study did not include the information on participants' diet. However, in the year 2005, new national nutritional guidelines for the preparation of meals in kindergartens and schools were adopted. Decreased total fat (especially saturated fat) and carbohydrate intake was advocated (18). Decreased dietary total fat intake is associated with decreased TC levels in children (32). According to the 
Statistical Office of Republic of Slovenia, over 75\% of 5 -year-old children visit kindergarten, where they receive up to four meals per day (19). Therefore, the observed decrease in TC level could be at least in part a consequence of changed public health policy.

These results are corroborated by data from the USA where a decrease in TC levels was also shown. They determined decreased total fat, saturated fat and cholesterol intake; specific measures leading to this fact were, however, not identified (33). In addition, the decrease in TC levels is similar in Slovenia and the USA. The TC mean value decreased by $0.27 \mathrm{mmol} / \mathrm{l}$ in Slovenian girls and by $0.25 \mathrm{mmol} / 1$ in Slovenian boys. In comparison, in 6- to 8 -year-old USA children the mean value decreased by $0.13 \mathrm{mmol} / \mathrm{l}$ from 1988 to 1994 to 2007 to 2010 (33).

Determination of TC level as a screening tool for dyslipidaemia was made due to the fact that a fasting sample is not necessary in this case. It was previously reported that increased TC levels detect elevated LDL-C levels with $44-50 \%$ sensitivity and $90 \%$ specificity (34). In order to diagnose dyslipidaemia more than one blood value is needed (35). In Slovenian children with elevated TC levels $>5 \mathrm{mmol} / \mathrm{l}$ a fasting lipid profile (TC, LDL, HDL and triglycerides) was carried out consequently. We unfortunately cannot report on these follow-up results, as the identities of screened children were anonymous.

The limitation of our study is that TC levels were not measured in a central laboratory but in laboratories of participating primary care facilities. The methodology, however, was the same, as were the analysers used throughout the study period. An additional limitation of this study is that data on whether the child has attended kindergarten have not been recorded.

\section{Association between BMI and TC levels}

The American Academy of Pediatrics recommends screening of children with a family history of premature CVD, a parental history of hypercholesterolaemia or when family history is unknown, and also screening of children with risk factors such as obesity, physical inactivity, hypertension, diabetes mellitus or smoking (35).

Recent studies have now reported that targeted screening of children with a positive family history missed many children with moderate hyperlipidaemia and a substantial number of children with likely genetic dyslipidaemias that would require treatment. They suggest that a universal screening is a better option (15).

In our study, there was no correlation between BMI and TC levels in either girls or boys. Therefore, by screening only overweight/obese children, we would not identify all children with hypercholesterolaemia. These results are in line with the fact that BMI percentiles do not discriminate effectively children with abnormal TC and LDL-C levels, as opposed to the adults $(36,37)$. Our results, alongside the described data from the literature, therefore further advocate a universal screening for hypercholesterolaemia especially in young children, enabling early prevention of CVD $(14,15)$.

\section{Conclusions}

The trend in the prevalence of overweight/obesity in pre-pubertal 5-year-old Slovenian children has stabilised and there was a significant negative trend in the prevalence of hypercholesterolaemia. We speculate that the changes in public health policies could be the cause of these trends. Interestingly, there was no correlation between BMI and TC levels, further advocating a universal screening for hypercholesterolaemia in children.

\section{Declaration of interest}

The authors declare that there is no conflict of interest that could be perceived as prejudicing the impartiality of the research reported.

\section{Funding}

The study was supported in part by the Slovenian National Research Agency grant numbers P3-0343 and J3-4116.

\section{Acknowledgements}

Authors would like to acknowledge the efforts of all primary care paediatricians and their teams who were involved in the collection of the data: Ajda Cimperman, Aleksandra Plut, Alenka Melink, Alenka Rus, Alenka Schweiger-Pavlakovič, Alenka Šumer-Pirc, Andreja Humar Žgank, Andreja Krebs, Andrejka Močnik, Angela Turk, Barbara Rijavec-Primc, Blaga Dalić, Bojana Pavlica, Božidar Weiss, Cvetka Golmajer, Darja Mikec, Eva Brecelj, Eva Dolničar-Šivic, Gordana Štrković-Tomaško, Helena Rihar, Igor Dovnik, Ildiko Sarnyai, Irena Gracar, Irena Klemenčič, Irena Kolman Krapež, Irena Penca, Irena Pretnar, Irena Vizovišek, Irena Zorc, Iva Kalinšek, Ivan Kauzlarič, Jasna Čuk-Rupnik, Jolanda Pavec-Repše, Jožica Lovrec Veternik, Jožica Selan, Katarina Koražija-Krajšek, Katarina Potušek Kuhar, Katja Šoštarič Likar, Lilijana Besednjak Kocijančič, Majda Accetto-Hočevar, Majda Gruden Večko, Margareta Seher-Zupančič, Marija Avsenik, Marija Kerin Grošelj, Marija Plut, Marija Vidovič, Marija Vukovič-Jamnik, Marina Grgič, Marjana Volarič, Marjetka Žefran Drole, Marta Semič-Maršič, Martina Soban, Martina Trobec Kralj, Mateja Jeranko, Metoda Drnovšek, Miranda Leban, Mirjam Grmek, Miroslava Cajnkar Kac, Mojca Jereb-Kosi, Mojca Švab-Zavratnik, Nada Gorjan Gortnar, Nada Jonko, Nada Poredoš, Nada Rončevič, Nada Saje-Hribar, Nadica Hleb, Neda Krapš Petek, Nives Prelesnik, Olga Turk-Slinkar, Polona Seme Ciglenečki, Romana Laktič, Simona Gradišek, Snežana Cvjetićanin, Snežana Ladika Žvar, Sonja Lobnik, Srečko Šuštar, Suzana Justinek, Suzana Škorjanc-Antolič, Šana Tratar, Vanda Hempt, Vera Šarf, Vida Škrabar Amon, Zdenka Goluh, Zdenka Korošec Kanič, Zlatka Zupančič, Ksenija Goste, Damjana Podkrajšek, Metka 
Kavčič-Obreza, Ivanka Štefančič, Nataša Vodičar, Majda Troha, Ivica Smajla, Bojan Štefančič, Jasna Jenko, Melanija Kocjan, Ružica Koterle, Beisa Žabkar, Marjeta Kuburič, Eva Bevc-Žunič, Polona Brcar, Nataša Fišer-Marčun, Cvetka Dragoš-Jančar, Metka Marolt, Mojca Pisanski, Helena Plevnik-Vodušek, Vlasta Porenta, Darja Rus-Srakar, Anka Sedej, Šarlota Starc, Olga Vrbošek, Marjeta Vrhovšek-Hribar, Barbara Weibl, Mojca Goršič-Frank, Eva Lovše-Perger, Leon Radolli, Marija Žiberna, Marjeta Maroša-Meolic, Valter Boltar, Tone Gortnar, Sonja Posega-Devetak, Nives Hočevar, Maruška Levstek-Plut, Janeta Kodrin-Pušnik, Štefka Zaviršek and Tončka Tratar.

\section{References}

1 Wang J. Standardization of waist circumference reference data. American Journal of Clinical Nutrition 200683 3-4.

2 Janssen I, Katzmarzyk PT, Boyce WF, Vereecken C, Mulvihill C, Roberts C, Currie C, Pickett W \& Health Behaviour in School-Aged Children Obesity Working Group. Comparison of overweight and obesity prevalence in school-aged youth from 34 countries and their relationships with physical activity and dietary patterns. Obesity Reviews 20056 123-132. (doi:10.1111/j.1467-789X.2005.00176.x)

3 Olds T, Maher C, Zumin S, Péneau S, Lioret S, Castetbon K, Bellisle, de Wilde J, Hohepa M, Maddison R et al. Evidence that the prevalence of childhood overweight is plateauing: data from nine countries. International Journal of Pediatric Obesity 20116 342-360. (doi:10.3109/ 17477166.2011.605895)

4 Moss A, Klenk J, Simon K, Thaiss H, Reinehr T \& Wabitsch M. Declining prevalence rates for overweight and obesity in German children starting school. European Journal of Pediatrics 2012171 289-299. (doi:10.1007/ s00431-011-1531-5)

5 Korsten-Reck U, Kromeyer-Hauschild K, Korsten K, Baumstark MW, Dickhuth HH \& Berg A. Frequency of secondary dyslipidaemia in obese children. Vascular Health and Risk Management 20084 1089-1094.

6 Cali AM \& Caprio S. Obesity in children and adolescents. Journal of Clinical Endocrinology and Metabolism 200893 S31-S36. (doi:10.1210/ jc.2008-1363)

7 Weiss R, Dziura J, Burgert TS, Tamborlane WV, Taksali SE, Yeckel CW, Allen K, Lopes M, Savoye M, Morrison J et al. Obesity and the metabolic syndrome in children and adolescents. New England Journal of Medicine 2004350 2362-2374. (doi:10.1056/NEJMoa031049)

8 Serdula MK, Ivery D, Coates RJ, Freedman DS, Williamson DF \& Byers T. Do obese children become obese adults? A review of the literature Preventive Medicine 199322 167-177. (doi:10.1006/pmed.1993.1014)

9 Berenson GS, Srinivasan SR, Bao W, Newman WP III, Tracy RE \& Wattigney WA. Association between multiple cardiovascular risk factors and atherosclerosis in children and young adults. The Bogalusa Heart Study. New England Journal of Medicine 1998338 1650-1656. (doi:10.1056/NEJM199806043382302)

10 Humphries SE, Whittall RA, Hubbart CS, Maplebeck S, Cooper JA, Soutar AK, Naoumova R, Thompson GR, Seed M, Durrington PN et al. Genetic causes of familial hypercholesterolaemia in patients in the UK: relation to plasma lipid levels and coronary heart disease risk. Journal of Medical Genetics 200643 943-949. (doi:10.1136/jmg.2006.038356)

11 Carroll MD, Kit BK, Lacher DA, Shero ST \& Mussolino ME. Trends in lipids and lipoproteins in US adults, 1988-2010. Journal of the American Medical Association 2012308 1545-1554. (doi:10.1001/jama.2012. 13260)

12 Kusters DM, de Beaufort C, Widhalm K, Guardamagna O, Bratina N, Ose L \& Wiegman A. Paediatric screening for hypercholesterolaemia in Europe. Archives of Disease in Childhood 201297 272-276. (doi:10.1136/ archdischild-2011-300081)

13 Ueland T, Vissers MN, Wiegman A, Rodenburg J, Hutten B, Gullestad L, Ose L, Rifai N, Ridker PM, Kastelein JJ et al. Increased inflammatory markers in children with familial hypercholesterolaemia. European Journal of Clinical Investigation 200636 147-152. (doi:10.1111/ j.1365-2362.2006.01613.x)
14 Wald DS, Bestwick JP \& Wald NJ. Child-parent screening for familial hypercholesterolaemia: screening strategy based on a meta-analysis. BMJ 2007335 599. (doi:10.1136/bmj.39300.616076.55)

15 Goldberg AC, Hopkins PN, Toth PP, Ballantyne CM, Rader DJ, Robinson JG, Daniels SR, Gidding SS, de Ferranti SD, Ito MK et al. Familial hypercholesterolemia: screening, diagnosis and management of pediatric and adult patients: clinical guidance from the National Lipid Association Expert Panel on Familial Hypercholesterolemia. Journal of Clinical Lipidology 20115 S1-S8. (doi:10.1016/j.jacl.2011. 04.003)

16 Uršič-Bratina N, Saje-Hribar N, Bratanič N, Žerjav-Tanšek M, Berce V, Kržišnik C \& Battelino T. Presejalno določanje holesterola pri pet let starih otrocih v Sloveniji. Zdravniški Vestnik 2003 72 7-10.

17 Avbelj M, Saje-Hribar N, Seher-Zupančič M, Brcar P, Kotnik P, Iršič A, Bratanič N, Kržišnik C \& Battelino T. Prevalenca čezmerne prehranjenosti in debelosti med pet let starimi otroki in 15 oziroma 16 let starimi mladostnicami in mladostniki v Sloveniji. Zdravniški Vestnik 200574 753-759.

18 Gabrijelcic Blenkus M, Pograjc L, Gregoric M, Adamic M \& Campa A. Smernice zdravega prehranjevanja v vzgojno-izobrazevalnih ustanovah (od prvega leta starosti naprej). Ljubljana: Ministrstvo za zdravje, 2005

19 Statistical Office of Republic of Slovenia. Slovene municipalities in numbers (http://www.stat.si/ObcineVStevilkah/Default.aspx?leto= 2011\&lang=eng, accessed 1.5.2013), 2011.

20 Pavcnik Arnol M, Bratina B, Kotnik P, Bratanic N, Zerjav Tansek M, Avbelj M, Krzisnik C \& Battelino T. Dyslipidemias in children and adolescent. Slovenska Pediatrija 200916 166-175.

21 Cole TJ, Bellizzi MC, Flegal KM \& Dietz WH. Establishing a standard definition for child overweight and obesity worldwide: internationa survey. BMJ 2000320 1240-1243. (doi:10.1136/bmj.320.7244.1240)

22 American Academy of Paediatrics. National Cholesterol Education Program: Report of the Expert Panel on Blood Cholesterol Levels in Children and Adolescents. Pediatrics 199289 525-584.

23 R Development Core Team (2009). R: a language and environment for statistical computing. In $R$ Foundation for Statistical Computing, Vienna, Austria (ISBN 3-900051-07-0, http://www.R-project.org, accessed March 22), 2013.

24 Cattaneo A, Monasta L, Stamatakis E, Lioret S, Castetbon K, Frenken F, Manios Y, Moschonis G, Savva S, Zaborskis A et al. Overweight and obesity in infants and pre-school children in the European Union: a review of existing data. Obesity Reviews 201011 389-398. (doi:10.1111/ j.1467-789X.2009.00639.x)

25 Blüher S, Meigen C, Gausche R, Keller E, Pfäffle R, Sabin M, Werther G Odeh R \& Kiess W. Age-specific stabilization in obesity prevalence in German children: a cross-sectional study from 1999 to 2008. International Journal of Pediatric Obesity 20116 e199-e206. (doi:10.3109/ 17477166.2010.526305)

26 Stamatakis E, Wardle J \& Cole TJ. Childhood obesity and overweight prevalence trends in England: evidence for growing socioeconomic disparities. International Journal of Obesity 201034 41-47. (doi:10.1038/ ijo.2009.217)

27 de Wilde JA, van Dommelen P, Middelkoop BJ \& Verkerk PH. Trends in overweight and obesity prevalence in Dutch, Turkish, Moroccan and Surinamese South Asian children in the Netherlands. Archives of Disease in Childhood 200994 795-800. (doi:10.1136/adc.2009.163709)

28 Ogden CL, Carroll MD, Curtin LR, Lamb MM \& Flegal KM. Prevalence of high body mass index in US children and adolescents, 2007-2008. Journal of the American Medical Association 2010303 242-249. (doi:10.1001/jama.2009.2012)

29 Romon M, Lommez A, Tafflet M, Basdevant A, Oppert JM, Bresson JL, Ducimetire P, Charles MA \& Borys JM. Downward trends in the prevalence of childhood overweight in the setting of 12-year schooland community-based programmes. Public Health Nutrition 200912 1735-1742. (doi:10.1017/S1368980008004278)

30 Aeberli I, Ammann RS, Knabenhans M, Molinari L \& Zimmermann MB. Decrease in the prevalence of paediatric adiposity in Switzerland from 
2002 to 2007. Public Health Nutrition 201013 806-811. (doi:10.1017/ S1368980009991558)

31 Direction de la Recherche, des Etudes, de l'Evaluation et des Statistiques, Ministère de la Santé. Nutrition et activité physique. Surpoids et obésité chez l'enfant. L'état de santé de la population en France: rapport 2009-2010. Paris, 2010.

32 Nicklas TA, Dwyer J, Feldman HA, Luepker RV, Kelder SH \& Nader PR. Serum cholesterol levels in children are associated with dietary fat and fatty acid intake. Journal of the American Dietetic Association 2002102 511-517. (doi:10.1016/S0002-8223(02)90117-3)

33 Hickman TB, Briefel RR, Carroll MD, Rifkind BM, Cleeman JI, Maurer KR \& Johnson CL. Distributions and trends of serum lipid levels among United States children and adolescents ages $4-19$ years: data from the Third National Health and Nutrition Examination Survey. Preventive Medicine 199827 879-890. (doi:10.1006/pmed.1998.0376)

34 Dennison BA, Kikuchi DA, Srinivasan SR, Webber LS \& Berenson GS. Serum total cholesterol screening for the detection of elevated low-density lipoprotein in children and adolescents: the Bogalusa Heart Study. Pediatrics 199085 472-479.

35 McNeal CJ, Dajani T, Wilson D, Cassidy-Bushrow AE, Dickerson JB \& Ory M. Hypercholesterolemia in youth: opportunities and obstacles to prevent premature atherosclerotic cardiovascular disease. Current Atherosclerosis Reports 201012 20-28. (doi:10.1007/ s11883-009-0072-0)

36 Lee JM, Gebremariam A, Card-Higginson P, Shaw JL, Thompson JW \& Davis MM. Poor performance of body mass index as a marker for hypercholesterolemia in children and adolescents. Archives of Pediatrics \& Adolescent Medicine 2009163 716-723. (doi:10.1001/archpediatrics. 2009.109)

37 Henriksson KM, Lindblad U, Agren B, Nilsson-Ehle P \& Rastam L. Associations between body height, body composition and cholesterol levels in middle-aged men the coronary risk factor study in southern Sweden (CRISS). European Journal of Epidemiology 200117 521-526. (doi:10.1023/A:1014508422504)

Received 9 July 2013

Revised version received 22 October 2013

Accepted 13 November 2013 